\title{
Penganggaran Daerah: Dinamika Politik Menuju Konsensus
}

\author{
Muhammad Aufa ${ }^{1^{*}}$ \\ ${ }^{1}$ Universitas Muhammadiyah Gresik, Jl. Sumatra 101, Gresik,Indonesia
}

DOI: http://dx.doi.org/10.30587/jiatax.v1i2.1026

\section{Abstrak}

This study aims to find out how the political process in preparing the budget carried out by local government organizers in reaching consensus. Budget politics is interpreted as an effort made by the actors (legislative and executive) to fight for the interests of the community. However, the implementation of budget discussions that produce budget legitimacy is still of a formal legal nature. The study was conducted using a critical paradigm approach with the analysis tool of Habermas communicative action theory. This theory emphasizes the realization of mutual communication over each other's consciousness without any pressure from any party. So that the communication model that is built is dialogic to achieve mutual understanding. To achieve effective communication, it must fulfill claims of validity consisting of comprehensivibility, truth, sincerity, and rightness. Data collection techniques using the method of observation, in-depth interviews and documentation. In the view of Habermas's communicative action theory, the rationality that guides the actions of the actors is instrumental rationality and target (strategic) rationality. Weaknesses in the validity of honesty claims have implications for the quality of consensus that is not good so it does not show a budget based on communicative rationality.

Jenis artikel: Empiris

Keywords: budget politics, consensus, communicative action theory

\section{Pengantar}

Sabarno (2008:16-17) menyatakan bahwa ada pergeseran paradigma dalam penyelenggaraan pemerintahan dewasa ini yaitu dari paradigma rule goverment menjadi good governance. Dalam paradigma rule goverment, penyelenggaraan pemerintahan, pembangunan, dan pelayanan publik didasarkan pada peraturan perundang-undangan (kebijakan) yang berlaku. Sedangkan, paradigma good governance dalam penyelenggaraan pemerintahan, pembangunan, dan pelayanan publik tidak terbatas hanya didasarkan pada suatu peraturan perundangundangan yang berlaku, tetapi juga adanya prinsip-prinsip penyelenggaraan pemerintahan yang

\footnotetext{
${ }^{*}$ Penulis yang sesuai:

E-mail: aufa@umg.ac.id

Afiliasi: Universitas Muhammadiyah Gresik
} 
baik yang tidak hanya melibatkan pemerintah tetapi juga perlunya adanya keterlibatan internal dan eksternal birokrasi.

Ada 10 prinsip baru pemerintahan (entrepreneurial government) menurut Osborne dan Gaebler (1992) dalam Geber (1994), yaitu: (1) pemerintahan katalis; (2) pemerintah milik masyarakat; (3) pemerintah yang kompetitif; (4) pemerintah yang digerakkan oleh misi; (5) pemerintah yang berorientasi pada hasil; (6) pemerintah yang berorientasi pada pelanggan; (7) pemerintahan wirausaha; (8) pemerintah antisipatif; (9) pemerintah desentralisasi; (10) pemerintah berorientasi pada pasar. Kesimpulan dari 10 perspektif baru pemerintahan ini adalah mewirausahakan organisasi sektor publik (Bastian, 2010:20). Konsep tersebut dikenal dengan istilah New Public Management (NPM).

Ide positif NPM yang telah disebarkan pada organisasi sektor publik tidak lepas dari adanya kritik seperti yang ditunjukkan oleh Connoly dan Hynman (2006) yaitu terkait perbedaan terhadap ideologi organisasi. Organisasi sektor publik khususnya pemerintah, ideologinya adalah memaksimalkan social welfare dengan mengutamakan pelayanan kepada masyarakat (public service) atau kepentingan publik (public interest). Sementara, tujuan yang menunggangi sektor privat adalah profit oriented yang merupakan bentuk atau manifestasi ideologi kapitalisme dengan menempatkan self-interest sebagai tujuan yang lebih dominan.

Kapitalisme sebagai dasar ideologi dari sistem ekonomi yang diterapkan saat ini perlu mendapat kritik sebagai sebuah sistem yang menindas, eksploitatif, bahkan rapuh bangunannya. Kapitalisme di negara berkembang berlangsung bukan untuk menciptakan keseimbangan, kesetaraan atau kesejahteraan bagi semua elemen masyarakat/bangsa di negeri bersangkutan. Tetapi, yang terjadi justru sebaliknya yakni menyebabkan timbulnya korban tanpa daya, yaitu terjadinya kemiskinan yang bukan hanya sebuah akibat, tapi juga sebuah keharusan sistemik bagi berlangsungnya etos dasar kapitalisme untuk lebih kaya dan serakah. (Dahana, 2015:9-11).

Sebenarnya, saat wawancara yang dilakukan oleh Geber (1994), Gaebler telah menjelaskan bahwa idenya tentang entrepreneurial government tidak berusaha untuk menjadikan organisasi sektor publik seperti perusahaan swasta (privat), melainkan adanya upaya tata kelola yang memiliki semangat entrepreneurship.

Perkembangan pengelolaan keuangan negara menuju pengelolaan keuangan yang efisien dan modern yaitu diterbitkan undang-undang nomor 17 tahun 2003 tentang keuangan negara (Bastian, 2010:43). Pada konteks daerah, regulasi terkait pengelolaan keuangan daerah diatur dalam Peraturan Pemerintah Nomor 58 Tahun 2005 tentang Pengelolaan Keuangan Daerah dan kemudian diturunkan setiap tahunnya dalam Peraturan Menteri Dalam Negeri Republik Indonesia (Permendagri) untuk menjadi acuan dalam penyusunan anggaran dan belanja daerah untuk tahun depannya.

Pemerintah Daerah (Bupati dan perangkatnya) dan DPRD memiliki kuasa besar dalam pengelolaan keuangan daerah. Meskipun, dalam perumusan anggaran daerah juga melibatkan partisipasi masyarakat melalui kelompok. Dan persoalan anggaran juga seringkali mencuat ke ruang publik. Namun, untuk memahami anggaran juga harus memiliki kecakapan dan tingkat pendidikan tertentu. Sementara, akses terhadap dokumen-dokumen yang terkait dengan anggaran tidak dimiliki oleh semua orang (Fuadi et al, 2002:1).

Aktor kuasa anggaran daerah (yaitu eksekutif dan legislatif) dalam penyusunan anggaran telah memenuhi tahapan-tahapan yang sudah ditentukan sesuai peraturan perundangundangan. Namun, masalahnya adalah tahapan-tahapan tersebut yang dijalankan masih terkesan setengah hati atau sekedar formalitas. DPRD cenderung bersikap oportunis dengan menjadikan proses penganggaran sebagai alat untuk memenuhi kepentingan pribadi. Sebagaimana hasil studi Abdullah (2004) yang menemukan bahwa ketika Pendapatan Asli Daerah (PAD) meningkat, maka yang memiliki dampak positif adalah anggaran untuk DPRD bukan anggaran untuk masyarakat (seperti pendidikan dan kesehatan).

Lebih lanjut, peran eksekutif dan legislatif dalam penyusunan anggaran daerah sebagai bentuk legitimasi produk kebijakan yang memiliki sifat legal formal. Hal ini bisa dilihat dari hasil desertasi Yamin (2015) yang ditunjukkan di bawah ini:

.....Eksekutif dan legislatif memanfaatkan "ruang" dan "waktu" dalam proses pembahasan dan penetapan anggaran daerah (APBD) untuk memainkan kekuasaannya. Para aktor menggunakan hak diskresi dan memanfaatkannya sebagai keleluasaan dalam mengalokasikan anggaran untuk kepentingan individu atau kelompok. Begitu pula saat pembahasan dan penetapan perubahan anggaran 
(APBD-P) juga menjadi ruang bagi kedua aktor tersebut. Kemitraan mereka hanya ditujukan untuk mengakomodir kepentingan keduanya sehingga interaksi terjadi dalam relasi kekuasaan. Itu berarti, legitimasi anggaran masih bersifat legal formal, hanya karena dihasilkan oleh eksekutif dan legislatif sebagai lembaga yang berwenang. Sebagai produk kebijakan, maka anggaran akan sangat ditentukan oleh "konsensus" antara eksekutif dan legislatif...

Berdasarkan uraian diatas, penelitian ini bertujuan untuk mengetahui bagaimana proses politik dalam penyusunan anggaran yang dilakukan penyelenggara pemerintahan daerah dalam mencapai konsensus.

\section{Tinjauan Teori}

\subsection{Perkembangan Penganggaran Sektor Publik}

Dalam perkembangannya, jenis penganggaran sektor publik dapat dibagi menjadi dua pendekatan. Pertama, pendekatan Tradisional (Traditional Budgeting). Kedua, pendekatan New Public Management (NPM) (Halim dan Kusufi, 2014:52; Mardiasmo, 2009:75).

Anggaran tradisonal partisipasi anggaran terjadi secara top down (sentralistik) sehingga kebutuhan yang relevan dengan kondisi di bawah kurang menjadi perhatian. Begitu juga untuk evaluasi atas kinerja, pada anggaran Tradisional akan mengalami kesulitan karena orientasinya hanya input. Berbeda dengan anggaran yang menggunakan pendekatan NPM, dimana orientasi anggaran berlangsung pada input, output dan outcome sehingga bisa diperhatikan kinerja terkait ekonomis, efisien dan efektifnya.

Pokok pikiran utama dalam NPM adalah berfokus pada pencapaian hasil, penetapan sasaran organisasi dan unit kerja yang jelas dengan indikator kinerja sebagai alat pengukur keberhasilan program, NPM juga mensyaratkan struktur organisasi dan kepegawaian lebih fleksibel, adanya peran pejabat pemerintah yang secara politis akan lebih bertanggung jawab dan dalam pola penganggaran serta fungsi pemerintah cenderung mulai berkurang melalui program privatisasi pemerintah (Hughes,2003).

Peraturan Pemerintah No. 58 Tahun 2005 pasal 39 tentang Pengelolaan Keuangan Daerah mengatur bahwa penyusunan anggaran berbasis kinerja akan berfokus pada keterkaitan penggunaan anggaran dengan keluaran dan hasil suatu program kegiatan termasuk pencapaian keluaran dan hasil. Penyusunan anggaran berdasarkan kinerja dilakukan berdasarkan capaian kinerja, indikator kinerja, analisa standar belanja, standar satuan harga pelayanan minimal.

Namun, APBD yang telah ditetapkan sebelum pelaksanaan anggaran bisa dilakukan perubahan dengan melakukan pembahasan antara Pemerintah Daerah dengan DPRD. Berdasarkan PP no. 58 tahun 2005 pasal 81, beberapa keadaan yang bisa dijadikan alasan dalam melakukan perubahan APBD, yaitu: perkembangan yang tidak sesuai dengan asumsi Kebijakan Umum APBD, keadaan yang menyebabkan harus dilakukan pergeseran anggaran antar unit organisasi, antar kegiatan, dan antar jenis belanja, keadaan yang menyebabkan saldo anggaran lebih sebelumnya harus digunakan tahun berjalan, keadaan darurat dan keadaan luar biasa.

\subsection{Konsensus: Legitimasi Politik Anggaran}

Fungsi penting anggaran tidak hanya sebatas untuk lingkup administrasi dan akuntansi, melainkan lebih luas yaitu pada aspek politik dan ekonomi. Fungsi anggaran pada aspek politik sebagai pengendalian akuntabilitas pemerintah atas alokasi yang berlebihan dari sumber daya yang ada dan juga sebagai pengendalian efisiensi pemerintah sehingga tidak terjadi adanya kelebihan pengeluaran. Upaya pengendalian ini identik model penganggaran kinerja yang menekankan pentingnya prinsip ekonomis, efisien dan efektif dalam realisasi anggaran.

Rubin (2000:2) menyatakan bahwa penganggaran publik merupakan gambaran relative power dari berbagai budget actors (individu dan organisasi) yang memiliki kepentingan atau preferensi berbeda dalam mempengaruhi outcomes anggaran untuk kepentingan masyarakat secara umum dan kelompok secara khusus. Mardiasmo (2009:65) menyatakan bahwa sebagai alat politik, maka perumus anggaran publik harus memiliki political skill, coalition building, kemampuan dalam bernegosiasi dan pemahaman tentang manajemen keuangan publik. 
Kemampuan-kemampuan tersebut perlu dimiliki oleh para aktor pembuat anggaran karena adanya kepentingan-kepentingan yang berbeda diantara para pelaku dalam memprioritaskan kebutuhannya. Anggaran yang sudah disepakati untuk disahkan merupakan bagian dari konsensus para penyelenggara pemerintahan daerah. Meyer (2012:29) menyatakan bahwa konsesnsus merupakan kesepakatan penuh yang diambil oleh sejumlah peserta atau kelompok terkait adanya isu-isu tertentu yang berkaitan dengan kepentingan, program politik dan aksiaksi yang diharapkan.

Dalam kajian Habermas (1975:309-310) dinyatakan bahwa norma-norma yang mengungkapkan kepentingan umum akan mendasarkan pada konsensus rasional. Sebaliknya, norma-norma yang didasarkan pada kepentingan kekuasaan diistilahkan sebagai kekuasaan normatif (Macht). Kekuasaan normatif pada kondisi khusus dimana kepentingan-kepentingan khusus melakukan penyesuaian-penyesuaian dengan melibatkan pihak-pihak yang memiliki kedudukan seimbang akan menghadirkan yang namanya: kompromi.

Proses kompromi memerlukan waktu banyak ketika pembahasan penyusunan anggaran terkait porsi belanja. Penyusunan belanja anggaran meliputi anggaran belanja rutin, belanja pembangunan dan belanja dewan (DPRD). Pada tahap penyusunan anggaran, ruang partisipasi masyarakat hanya disediakan dalam penyusunan anggaran belanja pembangunan. Meskipun tersedia ruang partisipasi masyarakat, namun belum ada jaminan usulan yang disampaikan oleh masyarakat akan menjadi prioritas belanja pembangunan (Fuadi et al.,2002:107).

Meyer (2012:40) menjelaskan adanya penilaian kompromi politik memiliki citra negatif karena masyarakat tidak memiliki cukup pengalaman yang terkait dengan hal tersebut. Hal ini karena sering kali calon legilatif dari partai politik melakukan kompromi yang tidak baik atau patut dipertanyakan. Artinya adanya partai politik ketika berkampanye menjanjikan sesuatu program, namun ketika mereka terpilih mereka malah menjauh dari klaim tersebut. Dan ini yang disitilahkan dengan kompromi malas atau setengah hati. Tindakan kompromi malas ini merupakan tindakan yang tidak dibenarkan sebagaimana disampaikan Meyer (2012:41):

"Dalam sebagian besar situasi, kompromi yang malas atau setengah hati merupakan bentuk penghianatan terhadap sasaran, nilai dan kepentingan yang diyakini peserta dengan tujuan untuk memenuhi sasaran lain yang benar-benar berbeda dan cenderung mau menang sendiri, dimana hal ini tidak dapat dibenarkan."

\section{Metode Penelitian}

\subsection{Alat Analisis: Teori Tindakan Komunikatif}

Penelitian ini dirancang dengan metode kualitatif. Dan paradigma yang digunakan adalah paradigma kritis dengan menggunaan teori tindakan komunikatif Habermas sebagai alat analisis. Dalam pandangan Creswell (2010:4) bahwa metode kualitatif merupakan bentuk metode pemahaman terhadap suatu makna terkait masalah sosial atau kemanusiaan yang diungkapkan oleh individu atau kelompok. Menurut Sugiyono (2012:1) obyek atau realitas sosial yang diteliti dari penelitian kualitatif bersifat holistik, komplek, dinamis dan penuh dengan makna.

Alat analisis yang digunakan pada penelitian ini adalah teori tindakan komunikatif Habermas. Pada teori ini Habermas berupaya menunjukkan bahwa tindakan memiliki dua orientasi yaitu orientasi sukses dan tercapainya kesepahaman (mutual understanding). Tindakan yang berorientasi pada kesuksesan ada dua istilah, yaitu: tindakan instrumental dan tindakan strategis. Pada tindakan instrumental, untuk mencapai sukses maka dilakukan melalui intervensi pada lingkungan fisik atau melalui sistem. Sedangkan pada tindakan strategis, untuk mencapai sukses dilakukan dengan mempengaruhi aktor/pelaku yang lainnya yang tidak terlepas dari norma sosial. Kemudian tindakan yang berorientasi kesepahaman yaitu tindakan komunikatif yang merupakan interaksi yang memungkinkan pelaku mewujudkan rencana ideal mereka. Habermas memahami bahwa ada aneka pendapat (kepentingan) yang ada pada masyarakat. Berbeda dengan teori Marlx yang mengambil jalan revolusioner untuk mencapai tujuannya, Habermas lebih menekankan pada perlu adanya kesepakatan-kesepakatan bersama atau konsensus untuk tujuan strategis (orientasi sukses) dan adanya saling kesepahaman. Konsensus dalam teori tindakan komunikatif habermas mensyaratkan adanya comprehensivibility, truth, sincerity, dan rightness. Klaim kebenaran (truth), artinya terdapat 
kesesuaian terhadap dunia alamiah dan objektif. Hal ini dilakukan melalui konfirmasi terhadap informan atas kebenaran dari konsep dan data anggaran daerah yang telah ada. Klaim ketepatan (rightness), artinya terdapat kesesuaian pada pelaksanaan norma-norma dalam kehidupan sosial. Hal ini dilakukan melalui penggalian informasi yang bersifat normatif. Klaim kejujuran (sincerity), artinya jika ada kesepakatan antara batiniah dengan ekspresi seseorang informan. Klaim komprehensibilitas (Comprehensivibility), artinya jika ketiga klaim sebelumnya telah terpenuhi dan bisa disepakati.

Habermas menganggap bahwa segala persoalan harus didialogkan dalam ruang yang bebas dari dominasi dalam rangka mencapai konsensus. Dialog dalam hal ini mengandaikan adanya kedudukan yang setara, karena itu Habermas menekankan pentingnya etika dalam komunikasi. Etika tersebut yaitu kondisi komunikasi yang menjamin sifat umum norma-norma yang dapat diterima dan menjamin otonomi individu melalui kemampuan emansipatoris sehingga menghasilkan pembentukan kehendak bersama lewat perbincangan.

\subsection{Satuan Kajian}

Unit analisis dalam penelitian ini adalah dinamika interaksi oleh penyelenggara pemerintahan daerah dalam proses mencapai konsensus yaitu menyusun dan menetapkan anggaran 2018 pada Kabupaten Pundung (bukan nama sebenarnya). Dinamika interaksi dalam satuan kajian penelitian ini adalah gerak atau kekuatan yang membentuk pola pikir, sikap dan laku yang terjadi dalam hubungan dan pengaruh antar penyelenggara pemerintahan daerah dalam menyusun anggaran (APBD) ketika penyampaian rencana Kebijakan Umum APBD (KUA) dan PPAS. Kemudian dilanjutkan adanya pembahasan bersama (Pemda dan DPRD) sampai terbit kesepakatan (konsensus) dalam bentuk Peraturan Daerah (Perda) APBD.

\subsection{Teknik Pengumpulan Data Dan Informan Penelitian}

Teknik pengumpulan data pada penelitian ini dengan melakukan wawancara secara langsung dan mendalam. Kegiatan wawancara secara mendalam bersifat pribadi sehingga diharapkan informan akan membuka informasi yang tersembunyi melalui topik tertentu.

Karena teknik ini bersifat pribadi maka kemampuan menangkap ekspresi para informan juga bersifat subjektif. Dan juga wawancara dilakukan secara tidak terstruktur supaya informasi yang disampaikan oleh informan bukan hasil olahan, melainkan suatu informasi secara apa adanya.

Selain wawancara, teknik pengumpulan data dilakukan dengan metode pengamatan (observasi) dan dokumentasi. Pengamatan dilakukan secara langsung pada lokasi situs penelitian. Pengamatan dilakukan untuk memahami pola sikap dan laku dalam interaksi yang dilakukan oleh informan. Nama-nama informan yang tertulis bukan nama sebenarnya Sedangkan, dokumentasi dilakukan dengan mengumpulkan dokumen yang menyajikan informasi yang mendukung berkaitan dengan tujuan penelitian.

Informan dalam penelitian ini terdiri atas para pemangku kepentingan di Pemerintahan Daerah Kabupaten Pundung. Informan yang dipilih merupakan para pelaku yang terlibat dalam penyusunan anggaran daerah sehingga mendukung penelitian ini, yaitu: pertama, pihak Eksekutif yang terdiri dari: pertama, Kepala Badan Perencanaan, Pembangunan, Penelitian dan Pengembangan Daerah (BAPPEDA). BAPPEDA mempunyai peran penting dalam mengoordinasi proses penerjemahan (breakdown) visi dan misi Bupati dalam bentuk rencana pembangunan jangka menengah daerah (RPJMD) yang akan menjadi pedoman arah pembangunan daerah selama lima tahun. RPJMD akan menjadi acuan dalam menyusun rencana kerja pemerintah daerah (RKPD). Penyusunan RKPD adalah tahapan awal dalam proses penyusunan APBD. Kedua, Kasubbid Bagian Penyusunan Anggaran Urusan Pemerintahan Wajib Badan Pendapatan, Pengelolaan Keuangan dan Aset Daerah (BPPKAD). BPPKAD memiliki tugas dalam mengoordinasi para Organisasi Perangkat Daerah (OPD) untuk melanjutkan tahapan dari perencanaan (KUA PPAS) hingga disahkannya APBD menjadi Perda dan Perbup Penjabaran APBD.

Informan dari lembaga Legislatif yang terdiri dari unsur pimpinan (wakil ketua) DPRD dan Ketua Fraksi yang merupakan anggota Badan Anggaran (Banggar) serta Mantan Anggota DPRD. Banggar DPRD merupakan alat kelengkapan DPRD yang dibentuk di awal masa 
jabatan anggota DPRD. Anggota Banggar terdiri unsur Pimpinan DPRD dan anggota dewan yang mewakili fraksi secara proporsional. Unsur Pimpinan DPRD adalah Ketua dan Wakil Ketua DPRD. Banggar memiliki kewenangan untuk melakukan koordinasi anggota DPRD dalam penyusunan APBD serta melakukan pembahasan bersama lembaga eksekutif (pasal 55 PP Nomor 16 tahun 2010).

\section{Hasil Penelitian dan Diskusi}

\subsection{Dinamika Aspirasi Masyarakat}

Para pendiri negara Indonesia telah menyepakati bahwa bentuk negara Indonesia adalah negara kesatuan republik Indonesia. Dengan berbentuk negara republik maka Indonesia menyatakan bahwa kedaulatan tertinggi berada di tangan rakyat dan tujuan pembangunan adalah untuk kepentingan rakyat. Dalam pandangan Habermas rakyat ini memiliki suatu dunia kehidupan (lifeworld) yang di dalamnya tertanam kesadaran-kesadaran intersubyektif. Kesadaran ini mengandung pandangan-pandangan dunia, keyakinan-keyakinan moral dan nilai-nilai bersama. Rasionalitas dunia kehidupan adalah rasionalitas komunikatif sehingga kedewasaan seseorang ketika orang tersebut semakin terintegrasi dengan dunia kehidupan masyarakatnya (Suseno, 2004).

Lebih lanjut, Suseno (2004) menyatakan bahwa masyarakat juga merupakan sebuah sistem dimana di dalamnya ada banyak institusi dan peraturan yang menata kehidupan masyarakat. Sistem ini kemudian meringankan beban komunikasi artinya tidak perlu adanya diskursus secara terus-menerus. Musrenbang dan Reses ini menyajikan suatu hubungan dunia kehidupan dengan rasionalitas sistem.

“....mereka kadang Musrenbang iku kumpul tok. Di Musrenbang itu tempat diskusi. ndak (tidak) terasa dikiro Musrenbang terus kumpul-kumpul tok gitu aja sih (sekedar kumpul)..... Tapi semua ada berita acara dan semua ada kita anulah harus mendokumentasikan semua kegiatan itu”, ungkap TU (Kepala Bappeda)

Akan tetapi, YA (Kasubid BPKAD) merasa tidak nyaman ketika kegiatan dalam forum Musrenbang dianggap formalitas. Meskipun, beliaunya mengakui bahwa forum Musrenbang tidak banyak usulan-usulan baru dan tidak terlalu dinamis. Di bawah ini cerita YA tentang suasana Musrenbang dan tahapannya:

“......Rasanya koq tidak nyaman kalau (Musrenbang) disebut formalitas. Disana nanti memaparkan apa yang terjadi dari bawah tadi. Ada dialog tapi tidak terlalu dinamikanya. Forum yang paling dinamis dalam penyusun anggaran ya mulai KUA PPAS sampai APBD."

Kondisi di masyarakat ada banyak kebutuhan yang harus dipenuhi. Akan tetapi, banyaknya kebutuhan tidak akan mampu untuk direalisasikan semua mengingat adanya keterbatasan sumber daya terutama sumber daya keuangan. Rasionalitas sistem yang mengejawantah dalam forum Musrenbang menetapkan suatu prioritas kebutuhan masyarakat. Masyarakat dilibatkan dengan sistem keterwakilan dari berbagai unsur yang ada. Sehingga ada sinergisitas dari berbagai elemen masyarakat. Hal ini menjadi wacana yang ingin direalisasikan oleh NU (Wakil ketua DPRD) dengan teman-teman Lembaga Swadaya Masyarakat (LSM) adalah adanya gerakan tiga pilar, tiga kekuatan yaitu: Pemerintah Desa, BPD dan tokoh masyarakat bekerja sama.

Sinergisitas ketiga pilar di atas dalam melakukan diskursus untuk terwujudnya kesepahaman akan menampilkan warna pembangunan yang partisipatif. Peran Tokoh Masyarakat dalam peran aktifnya memberikan pemikiran dan mengawal jalannya pembangunan di desa akan menambah legitimasi dan efektifitas kebijakan penyelenggara Pemerintahan Desa. Begitu juga kapasitas Perangkat Desa dan BPD perlu adanya peningkatan dalam upaya meningkatkan kualitas perencanaan dan penyelenggaraan pembangunan sehingga berjalan secara ekonomis, efisien dan efektif. Upaya peningkatan kapasitas perangkat dan BPD bisa diprioritaskan dalam realisasi Dana Desa, menurut NU. Sehingga Musrenbang di tingkat desa tidak lagi mengesankan sebagai forum formalitas dalam rangka memenuhi prosedur awal untuk dilanjutkan ke Musrenbangcam dan Musrenbangkab. Tetapi, dengan meningkatnya kapasitas Perangkat Desa diharapkan menyuguhkan kesungguhan dalam proses musyawarah untuk perencanaan pembangunan di desa. 
Dalam rangkah penyerapan aspirasi dari masyarakat, anggota DPRD harus melakukan kegiatan reses. Kegiatan reses dilakukan dengan mengundang atau menemui perwakilan masyarakat untuk mewadai usulan-usulan terkait dengan rencana pembangunan atau pengaduan permasalahan yang terjadi dimasyarakat. Terkait dengan efektivitas Reses dalam menyerap aspirasi masyarakat, wakil ketua DPRD, SA mengungkapkan:

"Iya. Ya sangat efektif lah untuk pembanding. Pembanding sebagai pembanding dari Musren, Musrenbang. Baik tingkat desa, kecamatan, sampai kabupaten sebagai pembanding. Nanti filternya kan di RKPD ketika usulannya sama kan tidak masalah satu yang masuk. Jadi, itu untuk mewadahi sama-sama aspirasi Musrenbangdes, aspirasi masyarakat tetapi kita harus paham bahwa Musrenbangdes karena aturan kita yakini tidak bisa mengakomodir semua usulan masyarakat. Karena aturannya yang terlibat di Musrenbangdes itu kan terbatas dan tidak semua kelompok."

Penjelasan SA diatas juga menyatakan adanya kemungkinan usulan yang berbeda antara Musrenbang dengan hasil Reses karena peserta yang berpartisipasi bisa berbeda. Hal ini karena dalam pelaksanaan Musrenbang tidak semua kelompok terlibat. Lebih lanjut SA menjelaskan bahwa dalam melakukan Reses, anggota DPRD tidak hanya mengumpulkan konstituen, tetapi bisa dilakukan dengan pihak-pihak yang memiliki pengaruh terhadap masyarakat di desa, termasuk dengan Perangkat Desa.

Namun, secara dominan peserta yang diundang dalam pelaksanaan Reses umumnya adalah para konstituen. Prioritas konstituen sebagai peserta Reses merupakan bentuk balas budi anggota dewan terhadap pemilihnya. Bentuk balas budi anggota dewan kepada konstituennya secara langsung adalah berupa uang transportasi (kehadiran) pada kegiatan Reses dan perjuangan dalam merealisasikan dana hibah yang direalisasikan dalam kegiatan bedah rumah atau bantuan usaha UMKM.

NU juga memaparkan terkait dengan biaya yang cukup besar yang harus dikeluarkan oleh calon anggota legislatif. Hal ini kemudian akan berdampak pada kinerja ketika ditetapkan sebagai anggota DPRD. Di bawah ini ujaran NU:

“....Sehingga ketika dia menjabat maka otomatis berupaya apapun hasil yang didapat yang bernilai uang akan diperhitungkan akan dikompensasikan dengan biaya yang dikeluarkan. Dan kalau itu yang terjadi saya jamin mereka tidak akan maksimal kinerjanya karena yang dipikirkan adalah bagaimana mengembalikan itu. Baik dari hasil dia menjabat maupun dari sumber yang lain, kerja sampingan dan kinerjanya tidak akan maksimal...."

Tingginya biaya dalam kontestasi politik dalam merebutkan kekuasaan baik menjadi anggota dewan maupun bupati tidak saja disebebakan oleh perilaku para aktor (calon legislatif dan calon eksekutif), namun persolan tersebut terjadi karena pengaruh cara pandang (mindset) masyarakat dalam memandang peran serta calon anggota legislatif yang berkontestasi. Setelah melihat perilaku dan tanggung jawab para kontestan baik yang ikut dalam pemilihan anggota legislatif maupun pemilihan kepala daerah (Bupati - wakil Bupati) ketika lolos (jadi) yang cenderung bersikap oportunis dengan tidak merealisasikan janji-janji ketika kampanye menjadikan sikap masyarakat yang memiliki hak suara menjadi pragmatis. Masyarakat mulai berpikir jangka pendek, yang penting dapat uang, tanpa mempertimbangkan kepentingan jangka panjang berupa kebijakan yang berpihak pada rakyat banyak.

Di samping itu, persoalan menjamurnya praktek politik uang dikarenakan pelaksanakan penegakan hukum di lapangan masih belum menunjukkan hasil. Jadi, untuk membangun demokrasi yang sehat perlu kerja bersama para penyelenggara dan kontestan pesta demokrasi prosedural mematuhi setiap ketentuan yang sudah ditetapkan. Dan juga pendidikan politik kepada masyarakat melalui berbagai forum, media dan keteladanan para pemimpin sehingga substansi demokrasi bisa memberikan dampak kesejahteraan bagi masyarakat.

\subsection{Makna dan Proses Politik Anggaran}

Caiden dan Wildavsky (2004) dalam Yamin (2015) menyatakan bahwa semua anggaran itu adalah politik, semua politik itu tentang anggaran, dan penganggaran itu seharusnya dipahami sebagai bagian dari permainan politik. Pernyataan Wildavsky dan Caiden tersebut di-amin-kan oleh salah satu anggota dewan yang menjadi anggota DPRD Pundung sejak di era Orde Baru, AN bahwa pembahasan anggaran muatannya penuh dengan politik. Makna politik yang 
dimaksud artinya DPRD berkewajiban untuk menyeleksi proyek-proyek yang sekiranya tidak berpihak pada masyarakat, maka DPRD berkewajiban untuk meluruskan.

Sementara, NU membedakan istilah politik anggaran dengan berpolitik dalam penganggaran. Politik anggaran merupakan upaya-upaya yang dilakukan oleh para aktor supaya anggaran bisa terpenuhi. Sedangkan, berpolitik dalam penganggaran memiliki hubungan yang erat dengan adanya kepentingan-kepentingan tertentu. Kepentingan tersebut diantaranya yaitu kepentingan pemerintah, kepentingan partai dan kepentingan pribadi atau kelompok tertentu.

Meskipun politik anggaran identik dengan masuknya kepentingan-kepentingan tertentu, bagi kepala Bappeda hal tersebut tidak terlalu dipedulikan selama kepentingan tersebut tidak keluar dari kesepakatan-kesepakatan dalam tahapan penyusunan anggaran. Berikut komentar kepala Bappeda:

"Politik anggaran iku piye (bagaimana)? anggaran itu sudah pasti kabeh (semua) kok. Pendapatan sudah dilihat bisa terukur...... ya biar dengan kepentingannya, yang penting tidak bisa keluar dari RPJMD begitu saja. Ini sekarang kampungku pingin (mau) mushola yo tidak bisa lek (jika) tidak ada di RPJMD. Yo rubahen sek (silahkan dirubah dulu) RPJMD, yo rubahen (ya silahkan dirubah) KUA PPAS sek (dulu), rubahen (ubah) RKPD begitu kan..."

Paparan diatas menunjukkan bahwa politik anggaran terikat dengan aturan-aturan yang sudah ditentukan. Dalam proses penganggaran, aturan-aturan tersebut terwujud dalam tahapantahapan yang tertib harus dilaksanakan. Sehingga upaya untuk keluar dari satu tahapan, maka harus merubah kesepakatan yang telah dibuat pada tahapan sebelumnya. Namun, menurut AH (Mantan Anggota DPRD periode sebelumnya), menyatakan bahwa pihak eksekutif dalam melaksanakan politik anggaran dengan melakukan perubahan draf pengesahan di luar hasil pembahasan. Dan beliau mengakui bahwa kemampuan pihak eksekutif dalam proses penyusunan anggaran jauh diatas para anggota legislatif. Mantan Ketua DPRD AR juga mengakui anggota DPRD sering kali lengah terhadap perubahan hasil kesepakatan yang sudah dilakukan pembahasan. Kemudian, AR menyarankan perlunya peningkatan kemampuan administratif bagi anggota DPRD untuk menghindari adanya kecurangan tersebut.

Bagi anggota legislatif, proses politik anggaran adalah bagian dari perjuangan untuk merealisasikan aspirasi masyarakat (konstituen) dari kegiatan Reses yang dituangkan dalam pokok-pokok pikiran (Pokir). Upaya untuk memperjuangkan kepentingan konstituen bagi anggota DPRD adalah selain sebagai wujud idealisme wakil rakyat, juga diakui oleh FA (Ketua Fraksi) merupakan bentuk kapitalisasi potensi suara untuk pencalonan anggota DPRD periode selanjutnya. Sementara bagi lembaga eksekutif, politik anggaran sebagai usaha menentukan prioritas program yang diserap melalui Musrenbangdes, Musrenbangcam dan Musrenbangkab. Anggaran Daerah selain memuat program-program yang diserap dari bawah (buttom up), juga memasukkan program-program top down yang merepresentasikan realisasi janji kampanye Bupati dan Wakil Bupati.

Secara umum para anggota DPRD memahami bahwa politik anggaran merupakan perjuangan yang dilakukan oleh penyelenggara pemerintahan dalam mengawal proses penyusunan dan pelaksanaan anggaran untuk tujuan kepentingan masyarakat. Namun, pertanyaan FA pada kalimat terakhir di atas menyiratkan adanya situasi yang tidak selalu ideal ketika menjalankan peran DPRD dalam politik anggaran.

DPRD dalam interaksi proses penyusunan anggaran memiliki kewenangan yang cukup kuat dalam menentukan persetujuan menjadi Peraturan Daerah (Perda). Hal ini karena RAPBD harus melalui persetujuan DPRD untuk bisa disahkan menjadi APBD. DPRD punya kewenangan menerima atau menolak setelah dilakukan pembahasan. Namun, AN selaku anggota DPRD saat ini yang paling lama masa baktinya mengeluh dengan kekuatan anggota legislatif sekarang ini. Beliaunya menilai kekuatan anggota legislatif saat ini jauh di bawah kekuatan anggota legislatif di era Orde Baru. Pada era Orde Baru dinamika pendapat para aktor yang melakukan pembahasan anggaran berlangsung saling mempertahankan. AN menganalogikan dinamika pendapat saat itu seperti pertandingan yang menarik.

Sementara saat ini, interaksi ketika pembahasan rancangan anggaran daerah tidak sedinamis pada saat Orde Baru. Hal ini karena kedua lembaga (eksekutif dan legislatif) cara berfikirnya sudah saling "enake yaopo ngono (bagaimana enaknya saja)" ketika ada persoalan. Sehingga dinamika interaksi dalam proses penyusunan anggaran jarang memicu adanya polemik. Lemahnya kekuatan legislatif saat ini juga tidak lepas dari status ketua DPRD yang 
memiliki hubungan pribadi yang sangat erat dan inferior dengan Bupati. Kondisi ini yang menjadi media kritik dalam pandangan Habermas sehingga teori tindakan komunikatif tidak bisa berjalan secara efektif. Prasyarat adanya kesepakatan bersama antar aktor mewajibkan adanya hubungan yang seimbang. Dialog komunikatif menghendaki adanya ruang bebas dari dominasi sehingga timbul otonomi individu.

Kompetensi komunikasi dalam pandangan Habermas harus dimiliki oleh individu melalui beberapa klaim validitas yaitu: kebenaran, kejujuran dan ketepatan dan komprehensif. Kebenaran menunjukkan bahwa kajian yang diangkat dalam komunikasi merupakan suatu fakta obyektif. Kejujuran menampilkan wujud ekspresi yang keberanian dalam mengeluarkan pendapat sesuai dengan dunia batin masing-masing, tanpa ada paksaan atau ketundukkan. Ketepatan mengharuskan kesesuaian dengan aturan-aturan yang ada. Jika ketiga ini terpenuhi dalam komunikasi maka klaim komprehensif akan terpenuhi dan menghasilkan suatu konsensus yang baik.

Pembahasan APBD pada tahapan awal (RKPD) berdasarkan hasil Musrenbang (yang diselenggarakan oleh pihak eksekutif) dan pokok-pokok pikiran (yang dihasilkan oleh pihak legislatif). Data-data yang diperoleh dari pembahasan pada masing-masing lembaga tersebut merupakan bentuk fakta obyektif dan ini memenuhi klaim validitas kebenaran. Namun, untuk klaim kejujuran dalam kompetensi komunikasi yang dibangun dalam proses penyusunan anggaran kualitasnya masih lemah. Kelemahan ini terlihat pada proses Musrenbang yang dilaksanakan mulai tingkat pemerintahan paling bawah yaitu Pemerintahan Desa sampai pada tingkat kabupaten yang cenderung bersifat formalitas. Sikap-sikap para anggota DPRD yang terkesan mudah kompromis ditambah hubungan antara ketua DPRD dengan Bupati yang sangat dekat mengurangi keberanian dalam mengekspresikan pendapat sesuai dengan nurani.

Sementara, pada klaim ketepatan relatif bisa terealisasi karena para aktor dihadapkan pada dilema anggaran yang juga akan berdampak negatif pada para Penyelenggara Pemerintahan Daerah sehingga harus mematuhi ketentuan-ketentuan yang menjadi norma (aturan) dalam penyusunan anggaran. Jadi, dari ketiga klaim validitas yang menjadi kompetensi kualitas komunikasi pada proses penyusunan anggaran daerah masih menyisakan kelemahan pada klaim kejujuran. Dampak ini akan mempengaruhi klaim komprehensif yang akan menilai kualitas konsensus hasil dari proses pembahasan anggaran menjadi kurang baik.

Pandangan Habermas sebagaimana yang dikutip Suseno (2004) menyatakan bahwa kebaruan teknologi dan tindakan untuk mencapai sasaran (strategi) bukan suatu impian masyarakat, melainkan yang penting adalah supaya komunikasi yang terbangun terbebas dari penjajahan oleh rasionalitas instrumental. Adanya sistem online dalam proses penyusunan anggaran daerah dan beberapa strategi seperti efisiensi merupakan bagian dari tujuan sasaran (strategis). sementara, dalam teori tindakan komunikatif Habermas yang terpenting dalam penyusunan anggaran daerah adalah terwujudnya pola komunikasi yang dilandasi oleh kejujuran dan tanpa tekanan antar aktor yang terlibat. Kejujuran akan menampakkan sebuah hasil konsensus yang murni dari proses dialektika, bukan lobi-lobi politik oleh segelintir orang yang pada ujungnya mengorbankan kepentingan besar masyarakat.

\subsection{Kompromi menuju Konsensus}

Menurut Meyer (2012:10) kompromi menekankan atas tindakan yang masuk akal dan diperlukan apabila tidak satupun pihak yang berpartisipasi memiliki cukup kekuatan untuk mengejar sasaran pribadinya secara pasti dan utuh. Kompromi sebagai upaya menekan biaya tinggi dalam upaya mempertahankan kepentingan satu pihak yang dominan.

Proses penyusunan anggaran daerah tidak lepas dari berbagai kepentingan. Situasi penyusunan anggaran daerah pada Kabupaten Pundung sempat tersendat dengan munculnya polemik. Sebenarnya polemik tersebut tidak berhubungan dengan substansi anggaran daerah 2018, tetapi berpengaruh terhadap keberlanjutan pembahasan RAPBD 2018, yaitu dana hibah tahun anggaran 2017 yang masih belum terealisasi. Sementara, tahun anggaran 2017 mendekati berakhir. Komentar yang bernada ancaman kemudian keluar dari beberapa anggota DPRD, seperti yang sampaikan oleh SA:

“...iya kemarin kita sempat mengultimatum itu karena kita ingin ada keseriusan saja dari Pemerintah Daerah untuk merealisasikan anggaran yang sudah kita sediakan di APBD nah salah satu contohnya kemarin adalah dana hibah yang sampek kita mbahas APBD itu belum direalisasi.. “" 
Pernyataan yang cukup keras juga dilontarkan oleh FA atas keterlambatan realisasi dana hibah tahun anggaran 2017:

"Intinya kita ini sudah sabar mas. Kita ini punya kewenangan terhadap pokok-pokok pikiran kita dan itu dibatasi hanya 2 milyar setiap anggota. Jadi, 100 milyar dari belanja (APBD) kita hampir 3 triliun, kecil kan? Padahal kewenangan anggaran ada pada kita, mau dibahas atau tidak tergantung kita........tiga tahun terakhir ini pencairannya mesti terlambat........jadi kalau ini tidak beres, maka pembahasan APBD tidak akan dilanjutkan."

Keterlambatan pengesahan APBD akan menyulut resiko bagi pembangunan di daerah dan terutama resiko bagi kedua aktor penyusun anggaran daerah yaitu pihak eksekutif (Bupati dan Wakil Bupati) dan semua anggota legislatif akan dikenakan sanksi penundaan pembayaran gaji selama enam bulan . Hal ini seperti yang disampaikan oleh NU di bawah ini ketika ditanya terkait batas waktu penetapan APBD:

“...Satu bulan sebelum tahun anggaran. Tahun anggaran kan satu Januari. Satu bulan sebelumnya berarti 30 November. Itu sesuai dengan Undang Undang (nomor) 23 (tahun 2004), PP 58/2005, Permendagri 12/2006 itu harus itu, kalau lebih dari ini ada resiko. Resikonya sudah sering di ekspos. Kalau sampek Desember ini belum beres aahhh itu Kepala Daerah dan DPRD tidak akan menerima gaji enam bulan kan gitu"

Beberapa perangkat aturan seperti Undangn-Undang, PP, dan Permendagri yang menjadi dasar dalam waktu penetapan APBD menjadi acuan atas sikap dan tindakan yang dilakukan oleh para pemegang kewenangan penyusunan anggaran daerah. Dalam bahasa Habermas, perangkat aturan ini merupakan sebuah legitimasi (Yamin, 2015). Upaya Penyelenggara Pemerintahan yang cenderung menghindari resiko yang terkait dengan penundaan gaji atas keterlambatan pengesahan APBD merupakan sikap pragmatis. Sehingga kompromi yang dibangun nuansanya lebih condong dimotivasi oleh rasionalitas instrumental (ketentuan yang mengatur anggaran daerah), bukan rasionalitas komunikatif (kesepahaman yang dibangun dari ruang dialektika yang sehat). Hal ini sesuai dengan kesadaran Habermas bahwa dunia modern telah menampilkan adanya rasionalitas instrumental dalam sistem telah berkembang lebih kuat dan menguasai dunia kehidupan. Habermas kemudian menyebut kondisi ini sebagai komunikasi yang terdistorsi (Juliawan,2004).

Preferensi para informan terhadap media saluran kompromi yang efektif, mereka memiliki pandangan yang berbeda. Ada yang menghendaki adanya forum informal dan sebagian yang lain proses dialektika tetap ingin berlangsung dalam forum formal. Seperti yang disampaikan oleh SA yang cenderung proses dialektika antara eksekutif dan legislatif menghendaki dilakukan secara formal. Sementara, pandangan lain disampaikan oleh FA:

“......Biasanya kalo kita mau membahas apa supaya lancar kita ketemu dulu secara informal. Sekarang jarang dilakukan oleh Bupati sekarang. ....Mestinya kalau mau bahas apa itu kita ngopi. Jadi kalau ada persoalan apapun itu selesai di luar, di dalam tidak ramai gitu" oleh TU:

Keinginan adanya media komunikasi yang berlangsung secara informal juga diinginkan

“.....Pembahasan ya kita lobi sebelum kita jelaskan itu lebih efektif menurut saya.... ya kita ngobrol-ngobrol itu lebih efektif. Kadang di forum itu pengalaman ya, penyelesaian di forum itu kadang kadang kaku ...... jujur aja ya "tidak semua (anggota) DPR itu paham"....."

Perbedaan cara pandang dalam memilih media yang efektif dalam melakukan kompromi dipengaruhi oleh intimitas hubungan antar aktor yang terlibat komunikasi. Jika hubungan diantaranya sudah terjalin secara akrab dan satu kelompok maka media komunikasi formal tidak akan menghambat proses kompromi. Sebaliknya, apabila hubungan pribadi atau partai kurang dekat, maka cara-cara komunikasi secara informal dianggap lebih efektif.

Dari beberapa informan pada penelitian ini, mereka lebih banyak memiliki kecenderungan menghendaki adanya komunikasi secara informal di sela-sela tahapan penyusunan APBD. Hal ini dianggap akan lebih efektif dalam dialektika antar Penyelenggara Pemerintahan Daerah. Hal ini sebenarnya sejalan dengan ide Habermas bahwa efektivitas tindakan komunikatif mengandung prasyarat, yaitu adanya kesamaan dan kejujuran dalam bahasa. Tingkat kepemahaman anggota DPRD yang tidak sama menurut Tugas akan 
mengganggu proses pembahasan anggaran atau terwujudnya tindakan komunikatif Penyelenggara Pemerintahan Daerah.

Namun, komunikasi informal (lobby) disamping memberikan manfaat efektivitas dan bahkan efisien waktu pembahasan, juga bisa membonceng dampak negatif. Komunikasi informal biasanya dilakukan oleh perwakilan dari kedua lembaga dalam hal ini adalah para pimpinan. Kemudian, pimpinan akan menggunakan kuasanya untuk memaksakan apa yang sudah disepakati dalam forum informal tersebut kepada anggota atau bawahannya. Sehingga kesepakatan pembahasan yang dilakukan oleh pihak eksekutif dengan para Anggota Dewan lebih bernuansa keterpaksaan (hegemoni kekuasaan). Sehingga gambaran dominasi kekuasaan ini menampilkan corak Penyelenggara Pemerintahan yang cenderung mengutamakan tujuan instrumental dan strategis (ketercapaian sasaran), bukan tujuan komunikatif (tindakan saling memahami).

\section{Kesimpulan}

Proses penyusunan anggaran daerah (APBD) dilakukan melalui tahapan-tahapan yang sudah ditetapkan. Tahapan-tahapan ini kemudian harus dilalui secara tertib. Tujuan dari penelitian ini memahami dan menganalisis secara kritis proses politik anggaran yang dilakukan penyelenggara pemerintahan. Proses penyusunan anggaran daerah adalah proses politik, teknokratis,dan birokratis yang melibatkan lembaga legislatif dan eksekutif. Namun, menurut YA penyusunan anggaran daerah lebih banyak diwarnai proses politik dibanding kegiatan teknokratis atau birokratis. Dalam diskursus beberapa informan, politik anggaran secara umum dimaknai sebagai upaya mengalokasikan anggaran daerah untuk kepentingan masyarakat.

Lembaga legislatif memiliki kewenangan yang kuat untuk menentukan hasil pembahasan berupa Perda APBD. Namun, kekuatan anggota legislatif saat ini jauh di bawah kekuatan anggota legislatif di era Orde Baru. Selain pola pikir yang pragmatis sehingga Anggota legislatif cenderung mudah melakukan kompromi, lemahnya kekuatan legislatif saat ini tidak lepas dari status hubungan Ketua DPRD yang sangat erat dan inferior terhadap Bupati. Kondisi ini akan menggugurkan tindakan komunikatif yang mensyaratkan adanya dialog yang seimbang tanpa dominasi diantara para aktor.

Dialektika proses politik penyusunan anggaran masuk dalam ruang kompromi. Namun, para informan memiliki pandangan yang berbeda mengenai media saluran kompromi. Ada yang menghendaki adanya forum informal dan sebagian yang lain proses dialektika tetap ingin berlangsung dalam forum formal.

Konsensus dalam bentuk ketetapan Peraturan Daerah tentang APBD sebuah keharusan dan terikat dengan batas waktu. Keterlambatan pengesahan APBD akan menyulut resiko bagi pembangunan di daerah dan terutama resiko bagi kedua aktor penyusun anggaran daerah yaitu pihak eksekutif dan legislatif yang akan dikenakan sanksi penundaan pembayaran gaji. Resiko yang kedua tersebut menjadikan para penyusun anggaran bersikap pragmatis. Sehingga kompromi yang dibangun nuansanya lebih condong dimotivasi oleh rasionalitas instrumental, bukan rasionalitas komunikatif.

\subsection{Implikasi}

Anggaran daerah merupakan gambaran pembangunan suatu daerah baik yang bersifat fisik maupun non fisik dalam rentang waktu satu tahun mendatang. Sehingga kemudian, anggaran daerah benar-benar harus disusun dengan baik oleh pihak penyelenggara pemerintahan dan juga mendapatkan perhatian dari masyarakat.

Tantangan adanya persoalan yang begitu komplek di daerah menuntut kecerdasan SDM para penyusun anggaran. Untuk itu kemudian, terlepas dari bahwa pemilu atau pilkada adalah kegiatan politik, peneliti berharap adanya kebijakan terkait proses pencalonan kontestan kegiatan politik tersebut yaitu peningkatan standar kualifikasi SDM yang layak (bukan elektabilitas).

Pandangan Habermas (1981) dalam Suseno (2004) menyimpulkan bahwa kompleksitas sistem disertai oleh rasionalisasi dunia kehidupan. Sehingga kemudian, selain peningkatan standar SDM aktor penyusun anggaran daerah yang perlu diperhatikan para pengambil kebijakan yang lebih tinggi, kesadaran masyarakat terhadap signifikansi anggaran 
daerah perlu diupayakan. Sehingga kemudian, rasionalitas sistem (Perda anggaran daerah) akan terwujud dari kualitas penyusun yang terstandar dan kesadaran masyarakat yang tinggi.

\subsection{Keterbatasan Penelitian}

Penelitian ini fokus pada proses penyusunan anggaran daerah. Sementara, dalam siklus pengelolaan keuangan daerah terkait dengan anggaran secara umum adalah penyusunan dan penetapan, pelaksanaan, penatausahaan, dan pertanggungjawaban. Dari siklus tersebut, peneliti hanya memotret pada tahapan penyusunan dan penetapan anggaran. Sehingga penelitian tentang pengelolaan keuangan daerah dengan menggunakan studi kritis Habermas bisa dilanjutkan pada siklus-siklus berikutnya supaya hasil yang didapatkan bisa lebih luas dan meningkatkan validitas penelitian.

Kebenaran suatu penelitian masih bersifat relatif, maka kemudian perlu dilakukan penelitian lebih lanjut dengan pendekatan studi kritis teori tindakan komunikatif Habermas untuk meneguhkan atau mengklarifikasi hasil penelitian yang sudah dilakukan. Dan juga keterbatasan dalam melakukan pengamatan dan interaksi dalam penelitian, maka perlu adanya penelitian lanjutan yang lebih mendalam sehingga dinamika politik anggaran daerah bisa terungkap lebih utuh.

\section{DAFTAR PUSTAKA}

Abdullah, S.2004. Perilaku Oportunistik Legislatif Dalam Penganggaran Daerah: Pendekatan Principal-Agent Theory. Conference Paper. https://www.researchgate.net/publication/303961090

Bastian. I. 2010. Akuntansi Sektor Publik: Suatu Pengantar. Edisi ketiga. Jakarta. Erlangga.

Caiden. N.. \& Wildavsky. A. 2004. The new politics of the Budgetary Process.

Connolly, C. dan N. Hyndman. 2006. The Actual Implementation Of Accruals Accounting: Caveats From A Case Within The UK Public Sector. Accounting, Auditing \& Accountability Journal, Vol. 19 Issue: 2, pp.272-290

Creswell, J.W. 2010. Research Design: Qualitative, Quantitative, and Mixed Methods Approaches. A. Fawaid. (penerjemah). Research Design:Pendekatan Kualitatif, Kuantitatif, dan Mixed. Edisi Ketiga. Pustaka Pelajar. Yogyakarta.

Dahana, R.P. 2015. Ekonomi Cukup - Kritik Budaya Pada Kapitalisme. Jakarta. Kompas

DeLeon, P. dan M. T. Green. 2000. Cowboys and the New Public Management: Political Curroption as a Harbinger. Graduate School of Public Affairs, University of Colorado (Denver).

Fuadi, A.H., D.Fatimah, R.Andriono dan W.W.Basjir. 2002. Memahami Anggaran Publik. Yogyakarta. Institute of development and economic analysis (Idea) Press.

Geber, Beverly. 1994. An interview with Ted Gaebler. Training; 31, 1; ABI/INFORM Global

Habermas, J. 1975. Legitimation crisis. Beacon Press. Terjemahan Y. Santoso. 2004. Krisis legitimasi. Yogyakarta. Qalam

.1981. Theorie Des Kommunikativen Handelns, Band I: handlungsrationalitat und gesellschaftliche rationalisierung. Suhrkamp Verlag. Terjemahan Nurhadi. 2006.Teori tindakan komunikatif: rasio dan rasionalisasi masyarakat. Buku satu Yogyakarta. Kreasi wacana

Halim, A. dan M. S. Kusufi. 2014. Teori, Konsep, dan Aplikasi Akuntansi Sektor Publik. Jakarta: Salemba Empat

Hughes, O. 2003. Public Management and Administration: An Introduction. Macmillan. Melbourne.

Juliawan, B.H. 2004. Ruang Publik Habermas: Solidaritas Tanpa Intimitas. Majalah Basis No. 11-12, Tahun ke 53 November-Desember 2004

Kamayanti, A. 2011. Akuntansi Atau Akuntansiana? Memaknai Reformasi Akuntansi Sektor Publik Di Indonesia. Jurnal akuntansi multiparadigma (JAMAL). Vo.2 no.3: 369-540.

Lampiran Permendagri Nomor 33 tahun 2017 tentang pedoman penyusunan anggaran pendapatan dan belanja daerah tahun anggaran 2018. Jakarta

Mardiasmo. 2009. Akuntansi sektor publik. Edisi.keempat. Yogyakarta. Andi 
Meyer, thomas.2012.kompromi jalan ideal menuju demokrasi. Jakarta. Freiderich-Ebertstiftung (FES).

Osborne dan Gaebler.1992. Reinventing Government. How to Entrepreneurial Spirit is Transforming the Public Sector. Addison Wesley.

Peraturan Pemerintah No. 58 Tahun 2005 Pengelolaan Keuangan Daerah. Lembaran Negara Republik Indonesia Tahun 2005 Nomor 140. Jakarta

-----------Nomor 16 tahun 2010 tentang pedoman penyusunan peraturan dewan perwakilan rakyat daerah tentang tata tertib dewan perwakilan rakyat daerah. lembaran negara republik indonesia tahun 2010 nomor 22. Jakarta

Premchand, A. 1983. Government Budgeting And Expenditure Controls: Theory And Practice. International Monetary Fund. Washington.

Robinson, M dan J. Brumby. 2005. Does Performance-Based Budgeting Work?: An Analytical Review of the Empirical Literature. IMF Working Paper 05/210. International Monetary Fund. Washington.

Rubin, I.S. 2000. The Politics of Public Budgeting: Getting and Spending, Borrowing and Balancing. Fourth Edition. Seven Bridges Press, LLC 135 Fifth Avenue New York

Sabarno. 2008. Memandu Otonomi Daerah, Menjaga Kesatuan Bangsa. Edisi1, Cetakan.2. Jakarta. Sinar Gambara

Sugiyono. 2012. Memahami Penelitian Kualitatif. Cetakan Ketujuh. Bandung. Alfabeta.

Suseno, F.M. 2004. 75 Tahun Jurgen Habermas. Majalah Basis No. 11-12, Tahun ke 53

Undang-Undang Republik Indonesia Nomor 17 Tahun 2003 Keuangan Negara. Lembaran Negara Republik Indonesia Tahun 2003 Nomor 47. Jakarta

Yamin, N.S. 2015. Aksi Kuasa Aktor Dalam Penganggaran Daerah: Perspektif Habermasian. Disertasi. Program Doktor Ilmu Akuntansi Pasca Sarjana Fakultas Ekonomi Dan Bisnis Universitas Brawijaya. Malang 